\title{
Perinatal Hypoxic-Ischemic Brain Injury Enhances Quisqualic Acid-Stimulated Phosphoinositide Turnover
}

\author{
${ }^{*}$ Chu-Kuang Chen, $†$ Faye S. Silverstein, ${ }^{*} \ddagger$ Stephen K. Fisher, \\ $\dagger$ Daniel Statman, and ${ }^{*} \uparrow \S$ Michael V. Johnston \\ ${ }^{*}$ Neuroscience Program, $\uparrow$ Departments of Pediatrics and Neurology, and $\ddagger$ Department of Pharmacology, \\ University of Michigan Medical School, and \$Center for Human Growth and Development, \\ University of Michigan, Ann Arbor, Michigan, U.S.A.
}

\begin{abstract}
In an experimental model of perinatal hypoxicischemic brain injury, we examined quisqualic acid (Quis)stimulated phosphoinositide (PPI) turnover in hippocampus and striatum. To produce a unilateral forebrain lesion in 7-day-old rat pups, the right carotid artery was ligated and animals were then exposed to moderate hypoxia ( $8 \%$ oxygen) for $2.5 \mathrm{~h}$. Pups were killed $24 \mathrm{~h}$ later and Quis-stimulated PPI turnover was assayed in tissue slices obtained from hippocampus and striatum, target regions for hypoxic-ischemic injury. The glutamate agonist Quis $\left(10^{-4} M\right)$ preferentially stimulated PPI hydrolysis in injured brain. In hippocampal slices of tissue derived from the right cerebral hemisphere, the addition of Quis stimulated accumulation of inositol phosphates by more than ninefold $(1,053 \pm 237 \%$ of basal, mean $\pm S E M, n=9)$. In contrast, the addition of Quis stimulated accumulation of inositol phosphates by about fivefold in the contralateral hemi-
\end{abstract}

sphere $(588 \pm 134 \%)$ and by about sixfold in controls $(631$ $\pm 177 \%, p<0.005$, comparison of ischemic tissue with control). In striatal tissue, the corresponding values were $801 \pm 157 \%, 474 \pm 89 \%$, and $506 \pm 115 \%(p<0.05)$. In contrast, stimulation of PPI turnover elicited by the cholinergic agonist carbamoylcholine, $\left(10^{-4}\right.$ or $\left.10^{-2} M\right)$ was unaffected by hypoxia-ischemia. The results suggest that prior exposure to hypoxia-ischemia enhances coupling of excitatory amino acid receptors to phospholipase $\mathrm{C}$ activity. This activation may contribute to the pathogenesis of irreversible brain injury and/or to mechanisms of recovery. Key Words: Quisqualic acid-Inositol phospholipidsHippocampus-Striatum-Carbamoylcholine-Perinatal -Hypoxia-ischemia. Chen C.-K. et al. Perinatal hypoxicischemic brain injury enhances quisqualic acid-stimulated phosphoinositide turnover. J. Neurochem. 51, 353-359 (1988).
Recent experimental evidence implicates the excitatory amino acid (EAA), glutamic acid, in the pathogenesis of irreversible neuronal damage from hypoxia-ischemia (Meldrum, 1985; Rothman and Olney, 1986). Brain regions enriched in EAA receptors, e.g., hippocampus and dorsolateral striatum, are especially vulnerable to selective ischemic neuronal injury (Jorgenson and Diemer, 1982).

In the developing nervous system and in cultured neural cells, selected EAA recognition sites are coupled to activation of phospholipase $C$, the enzyme which catalyzes the hydrolysis of membrane inositol phospholipids (PPI) (Sladeczek et al., 1985; Nicoletti et al., 1986b). The initial event involves the phopholipase C-mediated phosphodiesteratic cleavage of phosphatidylinositol 4,5-bisphosphate to yield two intracellular second messenger molecules, inositol 1,4,5-trisphosphate $\left(\mathrm{IP}_{3}\right)$ and diacylglycerol (Berridge et al., 1982; Berridge, 1984; for review, see Fisher and Agranoff, 1987). $\mathrm{IP}_{3}$ is sequentially dephosphorylated to inositol bis- and monophosphates $\left(\mathrm{IP}_{2}\right.$ and $\left.\mathrm{IP}_{1}\right)$ and then to free inositol. In the presence of $\mathrm{Li}^{+}$, inositol 1-phosphatase is inhibited and $\mathrm{IP}_{1}$ accumulates. Thus, the measurement of total inositol phosphate (IP) or IP ${ }_{1}$ accumulation in the presence of $\mathrm{Li}^{+}$provides a sensitive index of the extent of membrane PPI hydrolysis (Berridge et al., 1982). The glutamic acid agonist quisqualic acid (Quis), a potent excitotoxin in the neonatal brain (Silverstein et al., 1986), stimulates PPI hydrolysis in hippocampus and striatum in
Received December 28, 1987; revised manuscript received February 2, 1988; accepted February 4, 1988.

Address correspondence and reprint requests to Dr. M. V. Johnston at The University of Michigan Medical School, Neuroscience Laboratory Building, 1103 E. Huron, Ann Arbor, MI 48104-1687, U.S.A.
Abbreviations used: $\mathrm{CCh}$, carbamoylcholine; EAA, excitatory amino acids; GPI, glycerophosphorylinositol; IP, total inositol

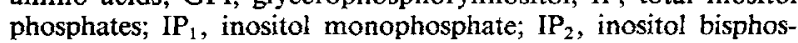
phate; IP $_{3}$, inositol trisphosphate; PPI, phosphoinositides; Quis, quisqualic acid. 
neonatal rat brain to a much greater extent than in adult brain (Nicoletti et al., 1986b).

In the immature brain, in vitro autoradiographic studies with $\left[{ }^{3} \mathrm{H}\right]$ glutamate demonstrate early focal reductions in $\left.{ }^{3} \mathrm{H}\right]$ glutamate recognition sites in target regions for irreversible neuronal damage (Silverstein et al., 1987). Although cerebral ischemia increases membrane phospholipid hydrolysis (Ikeda et al., 1986; Yoshida et al., 1986), there is no information about effects of hypoxia-ischemia on EAA stimulation of PPI turnover.

In this study, we used a well-characterized in vivo model of perinatal hypoxic-ischemic encephalopathy to examine the impact of an acute hypoxic-ischemic insult on EAA-coupled PPI turnover. In this model, right carotid artery ligation followed by exposure to $8 \%$ oxygen for $2.5 \mathrm{~h}$ in 7 -day-old rat pups predictably elicits unilateral forebrain injury ipsilateral to ligation (Johnston, 1983). Based on the observations that $\left[{ }^{3} \mathrm{H}\right]$ glutamate binding was reduced unilaterally in hippocampus and striatum $24 \mathrm{~h}$ after the hypoxicischemic insult, we sought to determine if these changes would be reflected in an altered ability of Quis to stimulate PPI metabolism in lesioned brain.

Basal and Quis-stimulated PPI turnovers were assayed in hippocampus and striatum $24 \mathrm{~h}$ after right carotid ligation followed by hypoxic exposure. To evaluate the specificity of any observed alterations in Quis-stimulated PPI turnover, in selected experiments, muscarinic agonist-stimulated PPI turnover was assayed concurrently. We found that hypoxicischemic injury resulted in a selective enhancement of Quis-stimulated PPI turnover in both hippocampal and striatal slices. A preliminary report of these results has been presented (Chen et al., 1987).

\section{MATERIALS AND METHODS}

myo-[2- $\left.{ }^{3} \mathrm{H}\right]$ Inositol $(15 \mathrm{Ci} / \mathrm{mmol})$ was purchased from American Radiolabeled Chemicals (St. Louis, MO, U.S.A.). Dowex-1 X8 ion-exchange resin (100-200 mesh; formate form) was obtained from BioRad (Richmond, CA, U.S.A.). Quis, carbamoylcholine ( $\mathrm{CCh}$ ), and other chemicals were obtained from Sigma Chemical Co. (St. Louis, MO, U.S.A.).

\section{Animal preparation}

Seven-day-old Sprague-Dawley rat pups were anesthetized with ether, and the right carotid artery was exposed and ligated as previously described (Johnston, 1983). After surgery, pups had a $1-\mathrm{h}$ recovery period with the dam and were then placed in a plastic chamber, warmed to $37^{\circ} \mathrm{C}$, and exposed to $8 \%$ oxygen $92 \%$ nitrogen for $2.5 \mathrm{~h}$. Pups generally tolerated the procedure well (10\% mortality). After $1 \mathrm{~h}$ of recovery from hypoxic exposure, pups appeared vigorous and were returned to the dam. Pups and littermate controls were killed by decapitation $24 \mathrm{~h}$ after hypoxia. This time interval was selected based on previous studies with this preparation, which consistently demonstrated histologic evidence of acute ischemic tissue damage and focal reductions in $\left[{ }^{3} \mathrm{H}\right]$ glutamate binding. In each experiment, tissue was obtained from 14-16 ligates and eight unoperated littermate controls; results from 11 experiments were included in this study.

\section{Tissue preparation}

Hippocampus and striatum were dissected out, and cross-chopped brain slices $(350 \times 350 \mu \mathrm{m})$ were prepared with a Mcllwain chopper. For each anatomic region, three pooled tissue samples were prepared: from the side of ligation (the right side), from the contralateral hemisphere, and from unoperated controls. Slices were suspended in buffer A [142 mM NaCl, $5.6 \mathrm{~m} M \mathrm{KCl}, 2.2 \mathrm{~m} M \mathrm{CaCl}_{2}$, $3.6 \mathrm{~m} M \mathrm{NaHCO}_{3}, 1 \mathrm{mM} \mathrm{MgCl}, 5 \mathrm{~m} M$ D-glucose, and 30 $\mathrm{m} M$ 4-(2-hydroxyethyl)-1-piperazineethanesulfonic acid $\left(\mathrm{HEPES}-\mathrm{Na}^{+}\right.$), $\mathrm{pH} 7.4$ ] and incubated at $37^{\circ} \mathrm{C}$ for $10 \mathrm{~min}$ with three intermediate buffer changes. After the slices settled, excess buffer was aspirated and 50- $\mu$ l aliquots of tissue (0.6-1 mg protein) were transferred to $10-\mathrm{ml}$ test tubes containing $4.0 \mu \mathrm{Ci}$ of $m y o-\left[2-{ }^{3} \mathrm{H}\right]$ inositol and $\mathrm{LiCl}(10$ $\mathrm{m} M$ ) in a final volume of $500 \mu \mathrm{l}$ of buffer $\mathrm{A}$.

\section{Assay of agonist-stimulated IP formation}

For each tissue sample, PPI turnover was assayed either in the absence (basal state) or in the presence of specified agonists. In preliminary experiments performed on tissue from normal 8-day-old pups, the dose-response curve for Quis at this developmental stage was determined. In each experiment, using pooled striatal and hippocampal tissues from at least 24 animals, the stimulatory effects of seven concentrations of agonist $\left(10^{-9}-10^{-3} M\right)$ were compared. In the next group of experiments using tissue slices from hypoxic-ischemic brain and from controls, assays at three different concentrations of Quis were included. Fifty microliters of Quis (final concentration: $10^{-6} M, \mathrm{n}=3 ; 10^{-4}$ $M, \mathrm{n}=9$; or $10^{-3} M, \mathrm{n}=1$ ), CCh (final concentration: $10^{-4}$ $M, \mathrm{n}=3$; or $10^{-2} M, \mathrm{n}=4$ ), or buffer A were added to each tube. In six of the experiments, Quis- and $\mathrm{CCh}$-stimulated PPI turnovers were assayed concurrently in aliquots from the same tissue slices. A continuous labeling paradigm was employed for the assay of PPI turnover due to its simplicity and sensitivity, as previously discussed (Fisher and Bartus, 1985).

After a 2-h incubation period at $37^{\circ} \mathrm{C}$, reactions were terminated by the addition of $1.7 \mathrm{ml}$ of chloroform/methanol (1:2 by volume). A total water-soluble IP fraction was separated from $m y o-\left[2-{ }^{3} \mathrm{H}\right]$ inositol by ion-exchange chromatography and quantitated as previously described (Fisher et al., 1984). For separation of the $\left[{ }^{3} \mathrm{H}\right]$ inositol metabolites, in five experiments, the water-soluble extracts were applied to ion-exchange columns containing Dowex-1 $\mathrm{X} 8$ resin (formate form) and individual IP fractions were eluted sequentially as described by Berridge et al. (1983). The largest fraction (49-65\%) of the label was recovered in $\mathrm{IP}_{1}$, with a smaller amount in glycerophosphorylinositol (GPI, 37-41\%). Less than 10\% of label was recovered in either $\mathrm{IP}_{2}$ or $\mathrm{IP}_{3}$. Whereas label in $\mathrm{IP}_{1}, \mathrm{IP}_{2}$, and $\mathrm{IP}_{3}$ is derived from the phosphodiesteratic breakdown of inositol lipids (Fisher and Agranoff, 1987), label in GPI may result from the deacylation of phosphatidylinositol that occurs in long-term incubations. To monitor the incorporation of labeled myo-inositol into the phospholipid fraction, a 0.2 $\mathrm{ml}$ aliquot from the lower organic phase was removed and allowed to evaporate, and then radioactivity was determined by liquid scintillation spectrometry following the addition of $10 \mathrm{ml}$ of ACS scintillation fluid (Amersham, Arlington Heights, IL, U.S.A.). Protein was measured according to Lowry et al. (1951). 
A group of experiments was performed to determine the time course of Quis-stimulated PPI hydrolysis in normal and hypoxic-ischemic hippocampal tissue. Hippocampal slices were incubated with $m y o-\left[2-{ }^{3} \mathrm{H}\right]$ inositol in the presence of $10^{-4} M$ Quis for $0.5 \mathrm{~h}, 1 \mathrm{~h}$, or $2 \mathrm{~h}$. A total water-soluble IP extract was prepared and $I P_{1}, I_{2}$, and $I P_{3}$ separated by ion-exchange chromatography.

Data are presented as means \pm SEM. Statistical significance was evaluated with paired $t$ tests.

\section{RESULTS}

In preliminary experiments, the dose-response curves for Quis-stimulated PPI hydrolysis were characterized (Fig. 1). In both hippocampus and striatum, an increased accumulation of ${ }^{3} \mathrm{H}$-IP could be detected at a Quis concentration of $10^{-7} \mathrm{M}$, and an optimum stimulation was obtained at a concentration of $10^{-5}-10^{-4} M$. Addition of Quis $\left(10^{-4} M\right)$ elicited an eight- to 10 -fold increase in ${ }^{3} \mathrm{H}$-IP release in the hippocampus, whereas a five- to sixfold increase was observed in the striatum. At a higher concentration of Quis $\left(10^{-3} M\right)$, stimulated PPI turnover was reduced; thus, a concentration of $10^{-4} M$ Quis was employed routinely.

The time course for the release of labeled IP from hippocampal slices is shown in Fig. 2. In the absence of agonists, label in either the IP fraction or in the

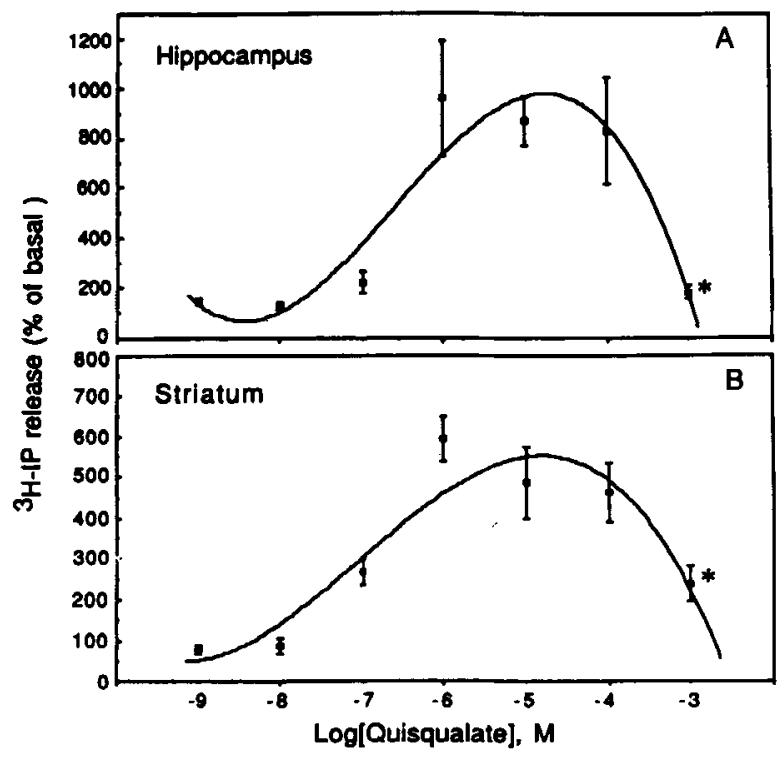

FIG. 1. A: Dose-response curve for Quis-stimulated release of IP in hippocampal slices from 8-day-old rat pups. Tissue slices were incubated with myo- $\left[2-{ }^{3} \mathrm{H}\right]$ inositol in the presence of the indicated concentrations of Quis. Reactions were stopped after $120 \mathrm{~min}$, and radioactivity in the IP fraction was determined (see Materials and Methods for details of assay). Values are expressed as percent of basal release; each value is the mean \pm SEM of five determinations. A computerized curve-fitting program (SYSTAT, Evanston, IL, U.S.A.) was used to model a third-order polynomial regression. B: Dose-response curve for corresponding values in striatal tissue assayed concurrently. ${ }^{*} p<0.01$, comparison with values obtained with $10^{-4}$ or $10^{-6} M$ Quis. individual $\mathrm{IP}_{1}, \mathrm{IP}_{2}$, and $\mathrm{IP}_{3}$ fractions increased progressively with time following up to $2 \mathrm{~h}$ of incubation for both control and ischemic tissues. The addition of $10^{-4} M$ Quis resulted in a significant increase in the labeling of the IP and IP, fractions. This enhancement of PPI turnover was two- to threefold higher in hippocampal tissue obtained from the hemisphere ipsilateral to the side of carotid ligation than that obtained from either the contralateral hemisphere or unoperated control animals (Fig. 2). The addition of Quis had little or no effect on the labeling of $\mathrm{IP}_{2}$ or $\mathrm{IP}_{3}$ under the conditions employed, presumably due to the rapid dephosphorylation of these IP. Prior hypoxia-ischemia had no effect on the basal release of IP. The differential ability of Quis to stimulate PPI turnover in ischemic tissue as monitored by the release of a labeled IP fraction was observed for both hippocampus and striatum (Table 1). In five of the nine separate experiments conducted with Quis at a concentration of $10^{-4} M, \mathrm{IP}_{1}$ was separated from the total IP fraction by ion-exchange chromatography. These results showed that increases in labeled $\mathrm{IP}_{1}$ were similar to those for the total IP fraction. In contrast, the muscarinic cholinergic agonist $\mathrm{CCh}$ stimulated PPI hydrolysis to a similar extent in both ischemic and nonischemic tissues. When Quis-stimulated IP release was expressed as percent of basal release, the selective ability of Quis to stimulate PPI turnover in tissues obtained from hypoxic-ischemic brain was confirmed (Fig. 3). Thus, a 10-fold increase in IP release was observed in the hippocampus ipsilateral to the side of ligation, whereas only five- to sixfold increases were observed in tissue obtained from the contralateral hippocampus or from control animals. Similarly, addition of Quis enhanced IP release by eightfold in the striatum ipsilateral ligation, but only by fivefold in tissue obtained from the contralateral side or from control animals. In contrast, CCh-stimulated IP release was similar in both ischemic and control tissues (Fig. 4).

Hypoxia-ischemia also caused an increased incorporation (approximately $80 \%$ ) of labeled inositol into inositol lipids under basal conditions $[271,000$ $\pm 56,000$ ipsilateral to ligation, $147,000 \pm 27,000$ contralateral to ligation, and $150,000 \pm 27,000$ control $(\mathrm{dpm} / \mathrm{mg}$ protein, $\mathrm{n}=11)]$. However, this increase in lipid labeling is insufficient to account for the increase in Quis-stimulated PPI turnover. Addition of either Quis or CCh had no predictable effect on the extent of lipid labeling (data not shown).

\section{DISCUSSION}

Our data demonstrate that in the developing nervous system an acute hypoxic-ischemic insult enhances the subsequent responsiveness of injured hippocampal and striatal tissue to the glutamate agonist Quis. Incubation with Quis elicits a significantly greater ${ }^{3} \mathrm{H}$-IP release from injured brain than from 


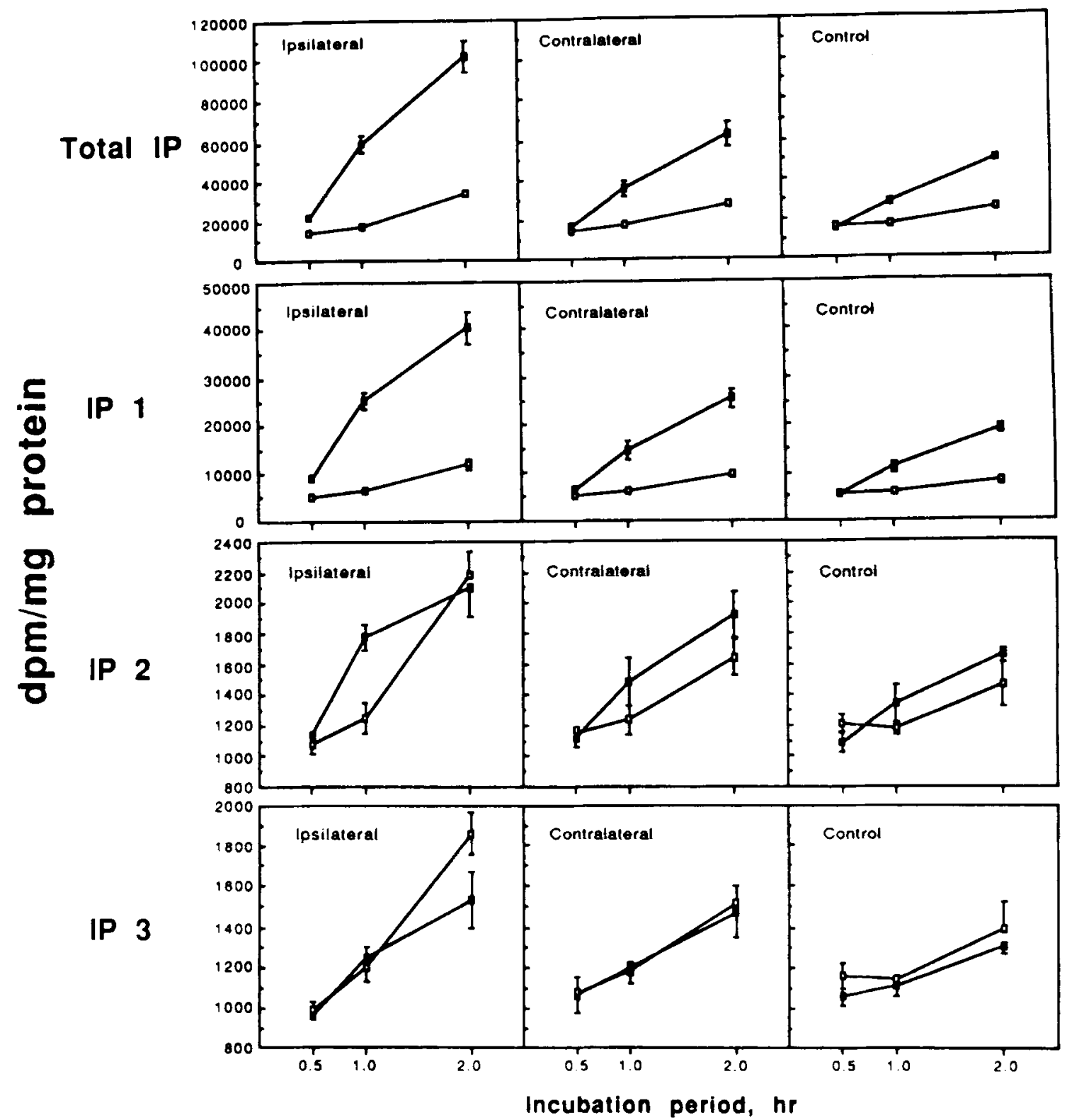

FIG. 2. Time course for Quis-stimulated release of $I P, I P_{1}, I P_{2}$, and $I P_{3}$ in hippocampal slices from the side of ligation ("ipsilateral'), the opposite hemisphere ("contralateral"), and control groups. Tissue slices were incubated with $m y 0-\left[2-{ }^{3} \mathrm{H}\right]$ inositol in the presence of $10^{-4} M$ Quis for three time periods: $0.5 \mathrm{~h}, 1 \mathrm{~h}$, or $2 \mathrm{~h}$. Values are expressed as dpm/mg protein; each value is the mean $\pm S E M$ of three

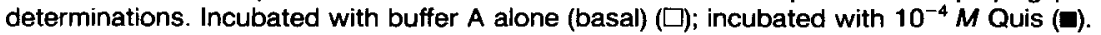

control tissue. In contrast, muscarinic stimulation of PPI hydrolysis in the injured tissue is unaffected. This suggests that hypoxia-ischemia causes a specific change in the Quis receptor-PPI second messenger complex. The enhanced response to Quis in ischemic tissue is most prominent at $10^{-4} \mathrm{M}$. In contrast to previous studies (Nicoletti et al., 1986a), we found that higher concentrations of Quis $\left(10^{-3} M\right)$ were less effective in both normal and lesioned tissue, perhaps because of direct neuronal toxicity of this glutamate agonist (Choi et al., 1987). However, the results demonstrate progressive increases in ${ }^{3} \mathrm{H}$-IP release with duration of Quis incubation in normal and lesioned hippocampus. They indicate that the tissue remains viable and that $10^{-4} M$ Quis does not exert significant in vitro neurotoxicity over this time interval.

One possible explanation for the increased effectiveness of Quis would be the availability of an increased number or higher affinity of glutamate receptors in the injured tissue. However, in vitro autoradiography in this experimental model indicates that at $24 \mathrm{~h}$ postligation, $\left[{ }^{3} \mathrm{H}\right]$ glutamate binding is reduced by $20-40 \%$ in ipsilateral hippocampus and by $20 \%$ in striatum (Silverstein et al., 1987). The recognition 
TABLE 1. Accumulation of ${ }^{3} \mathrm{H}-\mathrm{IP}$

\begin{tabular}{lrccc}
\hline & & \multicolumn{3}{c}{${ }^{3} \mathrm{H}-\mathrm{IP}(\mathrm{dpm} / \mathrm{mg}$ protein) } \\
\cline { 4 - 5 } \multicolumn{1}{c}{ Agonist } & $\mathrm{n}$ & Control & Ipsilateral & Contralateral \\
\hline Hippocampus & & & & \\
None & 11 & $14,520 \pm 3,800$ & $22,210 \pm 7,300$ & $18,080 \pm 7,900$ \\
Quis $\left(10^{-3} M\right)$ & 2 & $27,530 \pm 6,200$ & $35,320 \pm 3,300$ & $18,590 \pm 1,200$ \\
Quis $\left(10^{-4} M\right)$ & 9 & $92,290 \pm 38,900$ & $227,760 \pm 80,600^{a}$ & $74,670 \pm 24,300$ \\
Quis $\left(10^{-6} M\right)$ & 3 & $44,800 \pm 10,400$ & $65,410 \pm 8,900$ & $41,980 \pm 10,700$ \\
CCh $\left(10^{-2} M\right)$ & 4 & $26,000 \pm 6,600$ & $32,110 \pm 5,800$ & $27,760 \pm 5,800$ \\
CCh $\left(10^{-4} M\right)$ & 3 & $73,070 \pm 27,400$ & $92,720 \pm 33,100$ & $77,380 \pm 29,900$ \\
Striatum & & & & \\
None & 11 & $12,210 \pm 3,600$ & $16,950 \pm 7,100$ & $12,210 \pm 3,600$ \\
Quis $\left(10^{-3} M\right)$ & 2 & $21,660 \pm 1,000$ & $32,450 \pm 6,400$ & $26,860 \pm 4,000$ \\
Quis $\left(10^{-4} M\right)$ & 9 & $53,960 \pm 23,100$ & $111,430 \pm 44,400^{a}$ & $51,350 \pm 22,300$ \\
Quis $\left(10^{-6} M\right)$ & 3 & $19,770 \pm 4,200$ & $27,010 \pm 1,500^{a}$ & $20,690 \pm 2,300$ \\
CCh $\left(10^{-2} M\right)$ & 4 & $17,750 \pm 2,300$ & $23,990 \pm 3,500$ & $19,820 \pm 2,300$ \\
CCh $\left(10^{-4} M\right)$ & 3 & $45,370 \pm 14,900$ & $59,540 \pm 20,600$ & $53,180 \pm 27,100$ \\
\hline
\end{tabular}

In each experiment, in 14-16 7-day-old rat pups, the right carotid artery was ligated and pups were then exposed to $8 \%$ oxygen for $2.5 \mathrm{~h}$ (see Materials and Methods). Pups and littermate controls $(n=8)$ were killed $24 \mathrm{~h}$ later. Pooled tissue samples from the side of ligation ("ipsilateral") and the opposite hemisphere ("contralateral") were assayed for ${ }^{3} \mathrm{H}$-IP accumulation in the presence of Quis and $\mathrm{CCh}$ at the concentrations indicated (see Materials and Methods for details of procedure). Values are means \pm SEM.

${ }^{a} \mathrm{p}<0.05$, paired $t$.test, comparison with contralateral.

sites were visualized after incubation in $\left[{ }^{3} \mathrm{H}\right]-$ glutamate in $\mathrm{CaCl}_{2}$-containing buffer, which optimizes binding to quisqualate-preferring sites. Func-

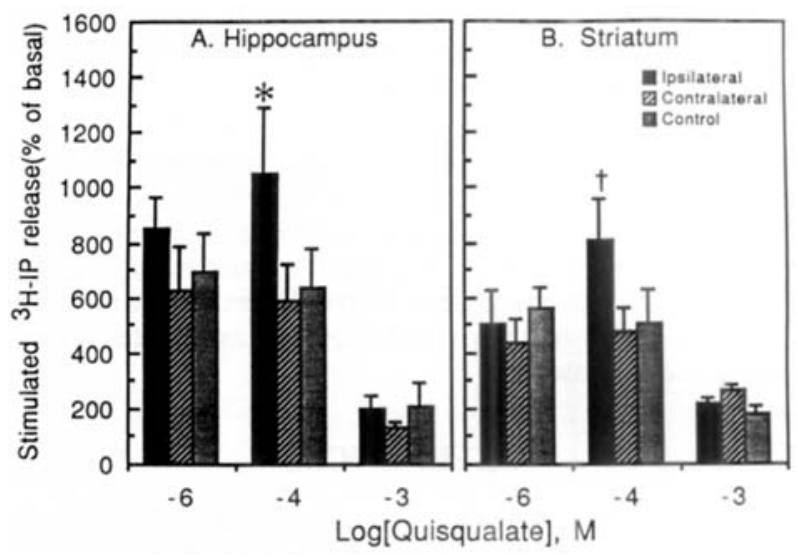

FIG. 3. A: Quis-stimulated release of IP in hippocampal tissue slices. Seven-day-old rat pups underwent right carotid ligation and subsequent exposure to $8 \%$ oxygen for $2.5 \mathrm{~h}$ ( $n=14-16$ pups) experiment; values from nine experiments included). Pups were killed by decapitation $24 \mathrm{~h}$ later. Hippocampal slices were prepared from hippocampus ipsilateral to ligation, from the contralateral hemisphere, and from untreated littermate controls $(n=8$ pups/experiment). Tissue slices were incubated with myo- $\left[2-{ }^{3} \mathrm{H}\right]-$ inositol in the presence of three concentrations of Quis $\left(10^{-6} M, n\right.$ $=3 ; 10^{-4} M, \mathrm{n}=9 ; 10^{-3} M, \mathrm{n}=2$ ). Reactions were stopped after $120 \mathrm{~min}$, and radioactivity in the total IP fraction was determined (see Materials and Methods for details of assay). ${ }^{3} \mathrm{H}-\mathrm{IP}$ accumulation in the presence of Quis was expressed as percent of ${ }^{3} \mathrm{H}-\mathrm{IP}$ release in the absence of agonist ("basal"). B: Corresponding values for Quis-stimulated IP release in striatum assayed concurrently. $" p<0.005, t p<0.05$, comparison of tissue derived from hypoxic-ischemic brain with tissue from the contralateral hemisphere with Student's $t$ test. tional loss of glutamate recognition sites at $24 \mathrm{~h}$ after unilateral hypoxia-ischemia appears to be a marker for brain regions destined for irreversible neuronal damage. The relationship between the glutamate recognition sites visualized with autoradiography and

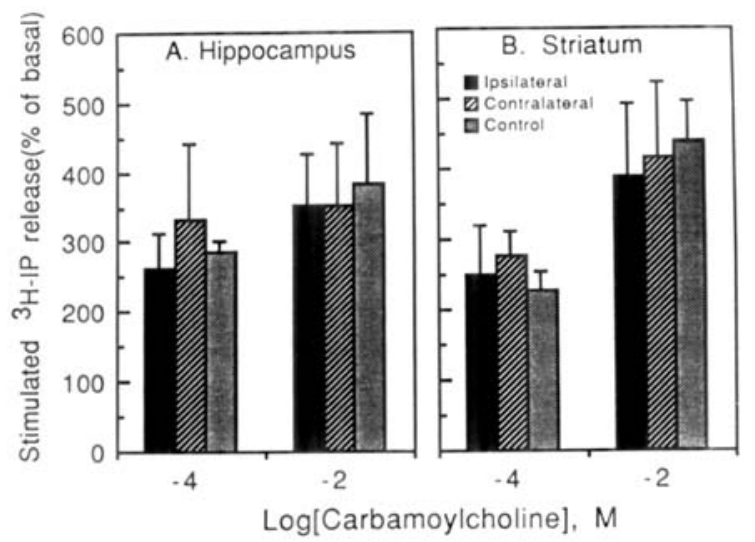

FIG. 4. A: CCh-stimulated release of IP in hippocampal tissue slices. Seven-day-old rat pups underwent right carotid ligation and subsequent exposure to $8 \%$ oxygen for $2.5 \mathrm{~h}$ ( $\mathrm{n}=14-16$ pups/ experiment; values from eight experiments included). Pups were killed by decapitation $24 \mathrm{~h}$ later. Hippocampal slices were prepared from hippocampus ipsilateral to ligation, from the contralateral hemisphere, and from untreated littermate controls $(n=8$ pups/experiment). Tissue slices were incubated with myo- $\left[2-{ }^{3} \mathrm{H}\right]-$ inositol in the presence of $10^{-4} \mathrm{MCCh}(n=3)$ or $10^{-2} \mathrm{M}$ CCh (n $=4)$. Reactions were stopped after $2 \mathrm{~h}$, and radioactivity in the total IP fraction was determined (see Materials and Methods for details of assay). Values are expressed as percent \pm SEM of basal release in the absence of agonist. B: Corresponding values for CCh-stimulated IP release in striatum assayed concurrently. In both brain regions, at each concentration of $\mathrm{CCh}$, no significant differences in CCh-stimulated ${ }^{3} \mathrm{H}$-IP release were found. 
the receptor subtype linked to PPI turnover is uncertain (Nicoletti et al., 1986a,b). There are no autoradiographic methods presently available which selectively label the glutamate recognition sites that are coupled to enhanced PPI turnover. Thus, it is conceivable that there is an isolated increase in the number or affinity of this receptor subtype which we could not measure. However, it is more likely that some of the $\left[{ }^{3} \mathrm{H}\right]$ glutamate sites which were reduced following hypoxia-ischemia are coupled to PPI hydrolysis.

EAA-stimulated PPI turnover in the immature rodent brain appears to be relatively specific for the quisqualate-preferring glutamate receptor. Both quisqualate and ibotenate stimulate PPI turnover considerably more in immature brain than in adults, but $\mathrm{N}$-methyl-D-aspartate and kainate are inactive (Nicoletti et al., 1986b). The enhanced EAA receptor stimulation of PPI turnover which we observed in hypoxic-ischemic brain resembles the enhanced stimulation of PPI hydrolysis elicited by ibotenic acid after kindling (Iadorola et al., 1986). The molecular mechanism underlying this response is unknown, but has been interpreted as a plastic response associated with changes in synaptic activity which accompany electrical hyperexcitability. We found no effect of $N$ methyl-D-aspartate on PPI turnover in hypoxic-ischemic infant brain, but ibotenate was not tested.

Increased incorporation of $m y o-\left[2-{ }^{3} \mathrm{H}\right]$ inositol into membrane phospholipids of injured tissue could result in an apparent enhanced response to agonist in hypoxic-ischemic brain. We found a consistent increase in myo- $\left[2-{ }^{3} \mathrm{H}\right]$ inositol labeling of membrane phospholipids in both hippocampus and striatum ipsilateral to ligation. Ikeda et al. (1986) reported that in a model of reversible cerebral ischemia there is an early increase in degradation of membrane PPI. Subsequently, in the postischemic period, membrane PPI content is restored (Yoshida et al., 1986). The increased myo- $\left[2-{ }^{3} \mathrm{H}\right]$ inositol incorporation we observed could reflect this compensatory resynthesis. However, this effect does not appear adequate to explain the response to Quis which we observed. Furthermore, increased lipid labeling of hypoxic-ischemic tissue would be expected to augment $\mathrm{CCh}$-stimulated PPI hydrolysis to a similar extent. This was not observed.

There is considerable evidence that ischemic neuronal injury is a consequence of a cascade of metabolic reactions that evolve progressively after the initial ischemic event (Kirino, 1981; Raichle, 1983). Enhanced glutamate-stimulated PPI hydrolysis elicited by hypoxia-ischemia may contribute to several potentially detrimental steps. The inositol lipids are a rich source of arachidonic acid, an important substrate for free-radical formation (Bazan, 1970; Ikeda et al., 1986; Westerberg and Wieloch, 1986; Abe et al., 1987). Furthermore, the metabolic cost of the futile cycle of receptor-mediated breakdown of PPI and its subsequent resynthesis is high; for each mole of phosphatidylinositol 4,5-bisphosphate degraded and resynthesized, five high-energy phosphates are consumed.

A variety of metabolic derangements in ischemic brain could also directly influence PPI hydrolysis. For example, elevated potassium levels, in the range seen in extracellular fluid of ischemic brain, can potentiate muscarinic-stimulated PPI hydrolysis in vitro (Eva and Costa, 1986). Intracellular levels of calcium rise in ischemic tissue (Simon et al., 1984) and may directly stimulate inositide phosphodiesterase (Fisher and Agranoff, 1987). It is also possible that the enhanced stimulation of IP release in injured tissue reflects a glial reaction to brain injury rather than a specific neuronal response. In cultured astrocytes, both glutamate and muscarinic agonists stimulate PPI metabolism (Pearce et al., 1986a,b).

EAA and muscarinic receptor coupling to PPI turnover is regulated developmentally; both receptors are coupled more efficiently to PPI hydrolysis at early developmental stages (Nicoletti et al., 1986b; Heacock et al., 1987). Enhanced activity could reflect allosteric changes in the conformation of the neurotransmitter recognition site, or in a protein coupling the receptor with phospholipase C; alternatively, a negative coupler could appear subsequently. The significance of this ontogenetic pattern is unknown, but does approximate early synaptogenesis and may bear some relationship to it. If this is so, the enhanced EAA receptor coupling we observed in injured brain may reflect an adaptive, possibly compensatory response of surviving neurons.

Acknowledgment: This work was supported by PHS grants 1 PO1 NS 19613 (M.V.J.), 1 KO8 NS01171 (F.S.S.), and NS 23831 (S.K.F.); grant R-326 from the United Cerebral Palsy Foundation (M.V.J.); and a basic research grant from the March of Dimes Birth Defects Foundation (M.V.J.). Holly Arft provided excellent assistance in preparing the manuscript.

\section{REFERENCES}

Abe K., Kogure K., Yamamoto H., Imazawa M., and Miyamoto K. (1987) Mechanism of arachidonic acid liberation during ischemia in gerbil cerebral cortex. J. Neurochem. 48, 503-509.

Bazan N. (1970) Effects of ischemia and electroconvulsive shock on free fatty acid pool in the brain. Biochim. Biophys. Acta 218, $1-10$.

Berridge M. J. (1984) Inositol triphosphate and diacylglycerol as second messengers. Biochem. J. 220, 345-360.

Berridge M. J. and Irvine R. F. (1984) Inositol triphosphate, a novel second messenger in cellular signal transduction. Nature 312, $315-321$

Berridge M. J., Downes P. C., and Hanley M. R. (1982) Lithium amplifies agonist dependent phosphatidyl inositol response in brain and salivary gland. Biochem. J. 206, 587-595.

Berridge M. J., Dawson R. M. C., Downes C. P., Heslop J. P., and Irvine R. F. (1983) Changes in the levels of inositol phosphates after agonist-dependent hydrolysis of membrane phosphoinositides. Biochem. J. 212, 473-482.

Chen C.-K., Silverstein F. S., Fisher S. K., Statman D., and Johnston M. V. (1987) Perinatal hypoxia-ischemia enhances quis- 
qualic acid stimulated phosphoinositide turnover. Soc. Neurosci. Abstr. 13, 755.

Choi D. W., Maulucci-Gedde M., and Kriegstein A. R. (1987) Glutamate neurotoxicity in cortical cell culture. J. Neurosci. 7, 357-368.

Eva C. and Costa E. (1986) Potassium ion facilitation of phosphoinositide turnover activation by muscarinic receptor agonists in rat brain. $J$. Neurochem. 46, 1429-1435.

Fisher S. K. and Agranoff B. W. (1987) Receptor activation and inositol lipid hydrolysis in neural tissues. J. Neurochem. 48, 999-1017.

Fisher S. K. and Bartus R. T. (1985) Regional differences in the coupling of muscarinic receptors to inositol phospholipid hydrolysis in guinea pig brain. $J$. Neurochem. 45, 1085-1095.

Fisher S. K., Figueiredo J. C., and Bartus R. T. (1984) Differential stimulation of inositol phospholipid turnover in brain by analogs of oxotremorine. $J$. Neurochem. 43, 1171-1179.

Greenamyre J. T., Penney J. B., Young A. B., Hudson C., Silverstein F. S., and Johnston M. V. (1987) Evidence for transient perinatal glutamatergic innervation of globus pallidum. $J$. Neurosci. 7, 1022-1030.

Heacock A. M., Fisher S. K., and Agranoff B. W. (1987) Enhanced coupling of neonatal muscarinic receptors in rat brain to phosphoinositide turnover. J. Neurochem. 48, 1904-1911.

Iadarola M. J., Nicoletti F., Naranjo J. R., Putnam F., and Costa E. (1986) Kindling enhances the stimulation of inositol phospholipid hydrolysis elicited by ibotenic acid in rat hippocampal slices. Brain Res. 374, 174-178.

Ikeda M., Yoshida S., Busto R., Santiso M., and Ginsberg M. D. (1986) Polyphosphoinositides as a probable source of brain free fatty acids accumulated at the onset of ischemia. J. Neurochem. 47, 123-132.

Johnston M. V. (1983) Neurotransmitter alterations in a model of perinatal hypoxic-ischemic brain injury. Ann. Neurol. 16, 511-518.

Jorgensen M. D. and Diemer N. A. (1982) Selective neuron loss after cerebral ischemia in the rat: possible role of transmitter glutamate. Acta Neurol. Scand. 66, 536-546.

Kirino T. (1981) Delayed neuronal death in the gerbil hippocampus following ischemia. Brain Res. 239, 57-69.

Lowry O. H., Rosebrough N. J., Farr A. L., and Randall R. J. (1951) Protein measurements with the Folin phenol reagent. $J$. Biol. Chem. 193, 265-275.

Meldrum B. (1985) Excitatory amino acids and anoxic-ischemic brain damage. Trends Neurosci. 8, 47-48.
Nicoletti F., Iadorola M. J., Wroblewski J. T., and Costa E. (1986a) Coupling of inositol phospholipid metabolism with excitatory amino acid recognition sites in rat hippocampus. $J$. Neurochem. 46, 40-46.

Nicoletti F., Iadarola M. J., Wroblewski J. T., and Costa E. (1986b) Excitatory amino acid recognition sites coupled with inositol phospholipid metabolism: developmental changes and interaction with alpha $a_{1}$-adrenoreceptors. Proc. Natl. Acad. Sci. USA 83, 1931-1935.

Nishizuka Y. (1986) Turnover of inositol phospholipids and signal transduction. Science 233, 305-312.

Pearce B., Albrecht B., Morrow C., and Murphy S. (1986a) Astrocyte glutamate receptor activation promotes inositol phospholipid turnover and calcium flux. Neurosci. Lett. 72, 335-340.

Pearce B., Morrow C., and Murphy S. (1986b) Receptor mediated inositol phospholipid hydrolysis in astrocytes. Eur. J. Pharmacol. 121, 231-243.

Raichle M. (1983) The pathophysiology of brain ischemia. Ann Neurol. 13, 2-10.

Rothman S. and Olney J. (1986) Glutamate and the pathophysiology of hypoxic-ischemic brain damage. Ann. Neurol. 19, 105-111.

Silverstein F. S., Chen R. C., and Johnston M. V. (1986) The glutamate agonist quisqualic acid is neurotoxic in striatum and hippocampus of immature rat brain. Neurosci Lett. 71, 13-18.

Silverstein F. S., Torke L., Barks J., and Johnston M. V. (1987) Hypoxia-ischemia produces focal disruption of glutamate receptors in developing brain. Dev. Brain Res. 34, 33-39.

Simon R. P., Griffiths T., Evans M. C., Swan J. H., and Meldrum B. S. (1984) Calcium overload in selectively vulnerable neurons of the hippocampus during and after ischemia: an electron microscopy study in the rat. J. Cereb. Blood Flow Metab. 4, 350-361.

Sladeczek F., Pin J. P., Recasens M., Bockart J., and Weiss S. (1985) Glutamate stimulates inositol phosphate formation in striatal neurons. Nature 317, 717-719.

Westerberg E. and Wieloch T. (1986) Lesions to the corticostriatal pathways ameliorate hypoglycemia-induced arachidonic acid release. J. Neurochem. 47, 1507-1511.

Yoshida S., Ikeda M., Busto R., Santiso M., Martinez E., and Ginsberg M. (1986) Cerebral phosphoinositide, triacylglycerol, and energy metabolism in reversible ischemia: origin and fate of free fatty acids. $J$. Neurochem. 47, 744-757. 